\title{
LEGAL FRAMEWORK FOR FREE LEGAL AID IN UKRAINE
}

\section{Etibar Vali Maharramli ${ }^{1}$}

${ }^{1}$ Postgraduate student of the State and Law Disciplines, International Law and European Union Law Department, H.S. Skovoroda Kharkiv National Pedagogical University, Kharkiv, Ukraine, e-mail: facultylaw@hnpu.edu.ua

Abstract. The article describes the content of regulations governing public relations in the field of provision of free legal aid depending on the level of their legal force. The author pays direct attention to the theoretical foundations of the concept of "legal regulation" and "mechanism of legal regulation". It is established that the legal basis for free legal aid in Ukraine is the Constitution of Ukraine, international treaties of Ukraine, laws of Ukraine, by-laws and departmental (interdepartmental) regulations. Also, the characterization of the legal framework for the provision of free legal aid is carried out by identifying its key features, namely: legal regulation of provision of free legal aid is carried out in three directions, ie general, sectoral and special; international legal acts in the field of the provision of free legal aid can be divided into general and concretized-contractual (bilateral international agreements); depending on the stages of formation of the free legal aid system normative-legal acts of the by-law level of legal regulation of provision of free legal aid 1) served as a normative-legal precondition of formation of legislative bases of provision of FLA; 2) ensured the formation of the FLA system by organizational and legal ways; 3) by specifying the provisions of the laws, created a mechanism for managing the FLA system and currently ensure its functioning; currently formation of the by-law level of legal regulation is provided solely by the Cabinet of Ministers of Ukraine; departmental legal regulation of FLA is characterized by dualism, which boils down to the specifics of subjective support for the formation of departmental norms, namely, the Ministry of Justice of Ukraine or the Coordination Center for Legal Aid Provision; memoranda of cooperation concluded between the Ministry of Justice of Ukraine or the Coordination Center for Legal Aid Provision and other bodies of the executive branch of power are legal acts of interdepartmental significance; administrative and legal regulation of the provision of free legal aid is also characterized by dualism, as it is carried out in two directions, including an organizational and legal and administrative and procedural ones; the legal framework for the provision of FLA serves as a basis for defining and characterizing the content of this category as a right and guarantee for the implementation of other constitutional human and civil rights.

Keywords: legal regulation, free legal assistance, law, by-law legal act, regulatory legal acts of the sub-legislative level.

JEL classification: K10, K20

Formulas: 0; fig.: 0; tabl.: 0; bibl.: 33

Introduction. Until recently, legal advice, protection and representation were out of reach for for many Ukrainian citizens. Many Ukrainians, particularly vulnerable population groups, simply could not afford the services of a lawyer or had no access to legal aid, which made their representation in court by a qualified professional impossible. Such a situation created an uneven playing field and did not help public confidence in government institutions in general and judicial fairness in particular, which is crucial for developing effective democratic mechanisms.

By adopting the Law of Ukraine On Free Legal Aid [1] in June 2011, Ukraine made the commitment to ensure legal protection of vulnerable population groups and improve access to justice by offering free legal aid (hereinafter referred to as FLA). However, one legal act is not enough to ensure the proper functioning of the FLA system. Accordingly, the government, represented by the authorized bodies, is 
obliged to properly form the legal ensurance of free legal aid, which will become the basis for its effective provision.

Literature Review. Some aspects of the described issues were studied by the scientists as follows: M.M. Antonovich, E.Yu. Bova, O.D. Boykov, T.V. Varfolomeeva, E.V. Vaskovsky, T.B. Vilchyk, O.O. Voronov, O. P. Galoganov, O.O. Govorukha, V.G. Goncharenko, A.V. Kozminykh, I.M. Kozkov, V.S. Lychko, R.G. Melnichenko, K.S. Pashchenko, S.V. Prylutsky, M.I. Rishko, N.Yu. Sakara, O.D. Svyatotsky, L.V. Tatsiy, P.V. Hotenets, Yu.T. Shramko, O.G. Yanovska and others. However, representatives of administrative and legal science almost did not pay attention to the administrative and legal framework for free legal aid; research on this issue is fragmentary and mainly limited to the scope of activities of the subjects of such aid (publications of O.V. Anpilogov, O.M. Bandurko, A.O. Galay, O.U. Synyavskya, K.O. Strukova). In particular, the current state of national legislation on providing the needy population groups with free legal aid and the place of administrative and legal regulation in it requires analises, which can serve as a basis for analyzing its shortcomings and identifying ways to eliminate them.

Aims. The objective of this article is to systematize and study the regulations governing the provision of free legal aid and, as a result, to characterize the legal basis for the provision of FLA by highlighting its specific features.

Methods. The author used the methods of logical comparison, systematization and generalization, which made it possible to achieve the goal of the study.

Results. Under the category of "legal regulation" representatives of the theory of state and law mainly understand bringing public relations in order, their legal consolidation and sorting out, protection and development carried out by the government through law and a set of legal means [2, p. 529]. At the same time, it is convenient to consider the legal framework of provision of free legal aid with the help of the tools of the legal regulation mechanism.

The concept of the legal regulation mechanism is one of the central ones in legal science. According to S.S. Alekseev, the above term may be understood as "a system of legal means (legal norms, legal relations, acts of implementation of legal norms) taken in its unity, through which the effective legal influence on relationship in society is made" [3, p. 364].

A norm of law is a universally binding rule of conduct established or authorised by the government, which is formulated in the form of clearly defined rights and responsibilities and is guaranteed by the coercive force of the state [4, p. 22]. Norms of law are incorporated mainly in regulations, ie in official documents of the governmental legislative or executive bodies of a law-making nature. It should be noted that the legal regulation of provision of free legal aid is carried out by a certain system of legislation, which consists of a significant number of regulations that differ from each other in many respects, including their name, legal force, procedure for adoption, and so on. By the way, from a certain point of view the law can be defined as "a system of norms" that applies to all cases of this particular kind, and in 
accordance with which the behavior of all persons that found themselves in a regulatory situation should be built $[5, \mathrm{p} .86]$.

Without any exaggeration, the Constitution of Ukraine takes a decisive place in the formation of legal framework for provision of free legal aid [6]. The fundamental importance of the latter in the legal system in general and the hierarchy of regulations governing the field of free legal aid in particular is determined by its supremacy and highest legal force, direct action, application throughout the country.

The system of legislation on provision of free legal aid is based, in particular, on the provisions of Chapter I of the Constitution of Ukraine, which outline the basic principles of the functioning of the state of Ukraine. According to Article 3 of the said law, "Human rights and freedoms and their guarantees determine the sence and orientation of the activity of the State. ... The affirmation and ensuring of human rights and freedoms of the human is the main duty of the State" [6]. In addition, the Basic Law of Ukraine sets forth the legal basis for guarantees of legality, namely: all state bodies, their officials, associations of citizens and other subjects of law must act pursuent to the Constitution and in accordance with the laws of Ukraine; laws and other normative legal acts are adopted on the basis of the Constitution of Ukraine and shall conform to it [6] (Articles 6, 8).

The provisions of Chapter II of the Constitution of Ukraine, which is devoted to the basic constitutional rights, freedoms and responsibilities of the human and citizen are worth special attention when characterizing the issues of provision of free legal aid. In particular, it is established that "Everyone arrested or detained... shall be given the opportunity to personally defend himself or herself, or to have the legal assistance of a defender" [6] (Article 29); "Everyone has the right to professional legal assistance. Such assistance is provided free of charge in cases envisaged by law"[6] (Article 59).

Continuing the provisions we have described, one cannot help mentioning the constitutional norms that outlined one of the tasks of the bar in Ukraine, ie ensuring the right to protection from prosecution and providing legal assistance in resolving cases in courts and other governmental bodies, not excluding, however, a possibility of using legal assistance of another defender of his/her rights or to exercise such protection personally [7, p. 9]

Article 9 of the Constitution of Ukraine makes it possible to identify the next level of legal regulation, which is international treaties, the binding nature of which was approved by the Verkhovna Rada of Ukraine, as a result of which the latter are part of the national legislation of Ukraine [6]. According to Article 19 of the Law of Ukraine On International Treaties of Ukraine, "if an international treaty of Ukraine, which entered into force in the prescribed manner, establishes rules other than those provided for in the relevant act of legislation of Ukraine, the rules of the international treaty shall be applied" [8]. The said indicates the reasonableness of the consideration of international documents in the field of provision of free legal aid at the next level of regulations following the level of legal regulation after the Basic Law of Ukraine.

Among the normative legal acts of the said level of legal regulation, the Convention for the Protection of Human Rights and Fundamental Freedoms [9] 
deserves special attention. Article 6 of the above defines the content of the right to a fair trial. In particular, it is established that every accused in a criminal offense has at least the right, in particular in the absence of sufficient funds to pay for legal assistance to a defender to receive such assistance free of charge when required by the interests of justice [9].

The General Assembly of the United Nations Organization (UN) adopted a resolution on the Principles and Guidelines on Access to Legal Aid in Criminal Justice Systems (The United Nations Principles and Guidelines on Access to Legal Aid in Criminal Justice Systems) No. 67/187 of 25.04. 2012 [10]. The said international document recognizes that free legal aid is also an important element of a fair, humane and efficient system of civil, administrative and family justice, grounded on the principles of the rule of law and which is aimed at ensuring access to legal aid in civil, administrative and family justice systems. In particular, the said resolution enshrines and discloses the essense of the principles of management (administration) of free legal aid field.

Issues of free legal aid were also covered in the Resolution of the Committee of Ministers of the Council of Europe On Legal Aid and Legal Advice No. (78) 8 of 02.03.1978 [11]. Paragraph 13 of the Resolution stipulates that legal consultations must be provided either free of charge or under the payment conditions of an amount that corresponds to financial capabilities of the person who requested the consultation.

In the context of consideration of international agreements in the field of free legal aid, it is necessary to refer to the provisions of Part 2 of Article 14 of the Law of Ukraine On Free Legal Aid, according to which "the right to free secondary legal aid shall be granted to citizens of the countries with which Ukraine has signed the relevant international treaties on legal aid, ratified by the Verkhovna Rada of Ukraine, as well as foreigners and stateless citizens in accordance with international treaties to which is Ukraine is a party, if such treaties prescribe free legal aid to be provided by the participating states to certain categories of persons" [1]. According to the official data of the Ministry of Justice of Ukraine as of September 13, 2019, Ukraine signed and ratified 61 bilateral international agreements in the field of international legal cooperation on legal aid [12].

Naturally, the Constitution does not directly regulate the issue of provision of free legal aid, but it is the basis for the adoption of laws and by-laws governing the relevant field of activity.

The laws of Ukraine play a central role in the mechanism of legal regulation of provision of free legal aid. And their importance in building the legal state must constantly grow, because the rule of law is an integral part of the latter. First of all, the rule of law is manifested in its strict compliance with all other regulations, as laws (after the Constitution) have the highest legal force. Laws regulate the most important spheres of state and public life, their rules are the core, the foundation of the formation and development of other legal norms [13, p. 55-57].

It is obvious that the main legislative act in the field of FLA is the Law of Ukraine On Free Legal Aid, which defines the essense of the right to free legal aid, 
the procedure for exercising this right, the grounds and procedure for providing free legal aid of two separate types (free primary legal aid (FPLA) and free secondary legal aid (FSLA)), government guarantees for the provision of free legal aid, principles of the state policy in the field of FLA, the system of subjects of FLA, etc.

A separate Chapter IV of the said Law is devoted to the management of the free legal aid system and its financing. In particular, the powers of the Cabinet of Ministers of Ukraine and the Ministry of Justice of Ukraine in the field of providing FLA, the procedure for financing free legal aid are clearly defined. It goes without saying that the provisions on appealing decisions on provision of free legal aid, actions or failure thereof of public authorities, local self-government agencies and officials (Articles 30-32 of the Law of Ukraine On Free Legal Aid) are important for ensuring the functioning of the FLA system.

A separate component of the legal regulation of free legal aid, which in particular is a government guarantee, which is in creation of equal opportunities for access of persons to justice, are codified legislative acts of the relevant procedural branches of law.

The Criminal Procedure Code of Ukraine [14] (hereinafter referred to as CPC) outlines free legal aid within one of the general principles of criminal procedures, ie ensuring the right to protection (Article 20 of the CPC of Ukraine). In addition, in terms of resolving issues of free legal aid the CPC of Ukraine defines the right of a suspect, an accused, "shall have services of a counsel provided at the cost of the state in the cases stipulated for in this Code and/or the law regulating provision of legal aid at no cost, including when no resources are available to pay for such counsel" (paragraph 3 of Part 3 of Article 42); the duty of the defense counsel to notify the body (institution) authorized by law to provide free legal aid if he is unable to appear to participate in the performance of procedural actions (Part 2 of Article 47); the procedure for engaging a defense counsel by an investigator, public prosecutor, investigating judge or court to provide protection, in particular on a gratuitous basis (Parts 2, 3 of Article 49); general rules of a blanket nature to ensure the financing of the costs of legal aid, which is free of charge for the suspect, accused (Part 3 of Article 120); the procedure for notifying the centers for the provision of FSLA on the detention of a person (Part 4 of Article 213), etc.

The Civil Procedure Code of Ukraine [15] (CPC of Ukraine) does not recognize the features of free legal aid, stating that the latter is provided in the manner envisaged by the law governing the provision of free legal aid (Article 15).

Considering the issue of civil proceedings, it should be noted that most subjects of the right to FSLA exercise it through access to civil proceedings. As a general rule, a representative in court may be a lawyer or another person who has reached the age of eighteen, has civil capacity and duly certified powers for representation in court. In this case, the authority of the representative of a natural person who is a subject of the right to FSLA and at whose request the decision to provide such assistance may be certified by an official of the Center for FSLA (Part 2 of Article 62 of the CPC of Ukraine). 
Except for the possibility of certifying the power of attorney of a representative of a free secondary legal aid center, the Code of Administrative Justice of Ukraine [16] (CAJ of Ukraine), as well as the CPC of Ukraine, does not set forth special procedures related to the provision of FSLA. According to Article 16 of the CAJ of Ukraine, the grounds and procedure for providing free legal aid in resolving cases in the administrative court are determined by the law governing the provision of FLA.

In accordance with the provisions of the Code of Ukraine on Administrative Offenses [17] (CAO) the persons to whom administrative detention was applied, fall down to a separate category of subjects of the right to FSLA, in connection with which the duty of bodies (officials) entitled to carry out administrative detention, to inform free secondary legal aid centers about each case of implementation of a relevant coercive measure, referring to the procedure established by the Cabinet of Ministers of Ukraine, unless a person defends himself/herself personally or invites a defender (Part 3 of Article 261 of the CAO). .

Article 271 of the $\mathrm{CAO}$ regulates the possibility of attracting a defender appointed by a Center for Free Secondary Legal Aid and its powers.

Detailing the provisions of the Law of Ukraine On Free Legal Aid at the legislative level the powers of individual entities providing FLA also find their reflection. Article 38-1 of the Law of Ukraine On Local Self-Government in Ukraine [18] defines own (self-governing) powers of executive bodies of village, settlement, city councils in the field of free legal aid. According to paragraph 39.1 of Part 1 of Article 26 of the said Law a range of items exclusively at the plenary sessions of the village, settlement, city council are addressed, in particular including "creation in accordance with the law at the expense of the local budget of institutions for free primary legal aid, appointment and dismissal of heads of these institutions, involvement of individuals or legal entities of private law to provide free primary legal aid in the manner prescribed by law" [18].

The Law of Ukraine On the Bar and Practice of Law [19] is also one of the key legislative acts in the field of FLA, which defines the legal framework for the organization of activities of the bar and practice of law in Ukraine, including requirements to the persons who can be lawyers, responsibility of lawyers, types of legal profession, the system of advocatory self-government, etc. [7, p. 15].

In accordance with the provisions of this legislative act, the bar self-government bodies should promote the functioning of the FLA system, for example, the assessment of the quality, completeness and timeliness of the FPLA that is carried out at the request of local governments by bar members, and FSLA provided at the request of the body (institution) authorized by law to provide free legal aid, commissions established for this purpose by regional bar councils [19] (Part 2, Article 25 of the Law of Ukraine On Advocacy and Advocacy). In addition, these councils appoint representatives of the bar to the competition commissions for the selection of lawyers to provide FSLA [19] (paragraph 6, Part 4 of Article 48 of the Law of Ukraine On the Bar and Practice of Law).

A number of by-laws are essential in the legal regulation of free legal aid. Unlike laws (acts of a primary nature that incorporate initial legal instructions), they 
are secondary acts that specify the provisions of laws or regulate the relations that are beyond the subject of legislative regulation. Such documents must be made up based on laws and they must not contradict them. The main objective of the latter is to solve specific problems.

The provisions of Article 27 of the Law of Ukraine On Free Legal Aid become indicative in the context of the abovementioned, according to which the Cabinet of Ministers of Ukraine shall do the following:

1) approves the procedure and terms of competition, and requirements to professional skills of the lawyers involved in the provision of free secondary legal aid; [20], which determine the mechanism of the competition for the selection of lawyers involved in the provision of FSLA and requirements to their professional level;

2) establishes the procedure and terms of signing contracts with lawyers that provide free secondary legal aid on a regular and temporary basis [21], which determine the mechanism for signing contracts with lawyers providing FSLA on a regular basis, and agreements with the lawyers who providing FSLA on an temporary basis by a reginal center on free secondary legal aid;

3 ) establishes the procedure for informing the Centers for free secondary legal aid on any case of detention [22], which establishes general requirements and mechanism for informing FSLA centers about cases of detention on suspicion of committing a crime, detention on the basis of a decision of an investigating judge, court on permission for detention for the purpose of pretext, applying administrative detention or choosing a precautionary measure in the form of detention. Fixing of the relevant procedure also ensures the implementation of the provisions of the CPC of Ukraine and the CAO mentioned above;

4) approves the Regulation on the Coordination Center for Legal Aid Provision [23], which is crucial for the institutional support of the FLA system, as it established the Coordination Center for Legal Aid Provision, which is a government institution (a public administration in the modern sense of administrative law) and belongs to the sphere of management of the Ministry of Justice of Ukraine in order to form and ensure the functioning of an effective FLA system in Ukraine, ensuring its availability and quality.

The above documents make up the list of by-laws.

An indisputable feature of the legal framework of the FLA system is the existence of the Decree of the President of Ukraine On the Concept of Free Legal Aid in Ukraine No. 509/2006 of June 9, 2006 [24]. The provisions of the Concept establish basic principles for the FLA system, in particular they set forth conducting experiments to test different organizational forms of FLA. As a result of generalization of outcomes of the said experiments a draft was developed and the Law of Ukraine On Free Legal Aid was adopted. After its adoption by the the State Target Program of formation of the legal aid system for 2013-2017, approved by the Cabinet of Ministers of Ukraine No. 394 of 13 February 2013 [25] the formation of the FLA system has been ensured by organizational and legal means. 
For most modern states there are two levels of legal regulation, incorporating a legislative one and the other regulatory, including an interdepartmental one [26, p. 13]. This can be attributed to the legal system of Ukraine. Thus, the legal regulation of FLA is driven not only by regulations of the Cabinet of Ministers of Ukraine (discussed above), but also by departmental regulations that can be adopted by the Ministry of Justice of Ukraine and the Coordination Center for Legal Aid Provision.

A number of orders of the Ministry of Justice of Ukraine are important for the FLA system. For example, the order of the Ministry of Justice On approval of quality standards for free secondary legal aid in criminal proceedings No. 368/5 of February 25,2014 [27] defined the quality standards for free secondary legal aid in criminal proceedings as a set of basic characteristics of the government-guaranteed protection model provided for by international legal acts, the legislation of Ukraine, within the framework of which and taking into account the agreed legal position of the defense, the defender is independent in choosing strategies and tactics of protection in criminal proceedings to actively and reasonably protect the rights, freedoms and legitimate interests of the client by all means not prohibited by law [28].

The regulatory documents regarding the procedures for granting FLA, including the following orders of the Ministry of Justice of Ukraine are worth attention, namely:

- On approval of the Standard Regulations on a Free Primary Legal Aid Provider, No. 483/5 of March 28, 2012 [29];

- On approval of the Operating procedures of Public Reception Offices for free primary legal aid, No. 2047/5 of September 21, 2011 [30].

Many of the issues related to the modeling and organizational support of the renewed FLA system were resolved by orders of the Coordination Center for Legal Aid Provision.

The most important orders of the latter include those related to the establishment and organization of legal aid bureaus, providing access to electronic services of the Ministry of Justice of Ukraine and approving the rules of operating procedures of the governing board of regional and relevant local centers for the provision of FSLA [31].

The Guidelines for the organization of free legal aid by local centers for provision of free secondary legal aid [32] should be specifically mentioned. Given that the Law inexhaustibly regulates the procedures related to the provision of FSLA, the Guidelines allowed to organize and stabilize the work of the centers for provision of free secondary legal aid and start collecting data that was necessary to adjust the FLA provision system.

Discussion. A large number of memoranda are worth mentioning including those on cooperation between the Ministry of Justice of Ukraine or the Coordination Center for Legal Aid Provision, and other bodies of the executive branch of power (such as the National Police of Ukraine [33]), which appear to be legal acts of interdepartmental significance. However, the latter are not subject to the state registration, because they are aimed at organizing the implementation of existing decisions and do not contain new legal norms [2, p. 365]. 
Conclusions. Summarizing the above, we must state that the legal framework for the provision of free legal aid in Ukraine incorporates the Constitution of Ukraine, international treaties of Ukraine, laws of Ukraine, by-laws and departmental (interdepartmental) regulations. The analysis of the legal framework for the provision of free legal aid made it possible to identify the following key features of the above regulations:

- legal regulation of free legal aid is carried out in three directions: 1) general (the Constitution of Ukraine, Law of Ukraine On Free Legal Aid, by-laws, etc.); 2) sectoral (The Criminal Procedure Code of Ukraine, The Civil Procedure Code of Ukraine, the Code of Administrative Justice of Ukraine) and special (bilateral international agreements in the field of international legal cooperation, memoranda of cooperation);

- they determine the international legal guidelines for ensuring the realization of human and civil rights and freedoms by providing FLA, which come into force for Ukraine by recognizing the former at the official level; 2) concretized-contractual (bilateral international agreements) - they contain rules for the provision of free legal aid at the national level within bilateral relations in the field of international legal cooperation;

- normative-legal acts of the by-law level of legal regulation of provision of free legal aid depending on the stages of formation of the free legal aid system 1) served as a normative-legal precondition of formation of legislative bases of provision of FLA; 2) ensured the formation of the FLA system by organizational and legal ways; 3 ) by specifying the provisions of the laws, created a mechanism for managing the FLA system and currently ensure its functioning;

- formation of the by-law level of legal regulation of the current FLA sphere is provided solely by the Cabinet of Ministers of Ukraine;

- departmental legal regulation of FLA is characterized by dualism, which boils down to the specifics of subjective support for the formation of departmental norms, namely, the central body of the executive branch of power (the Ministry of Justice of Ukraine) and a specially created public administration entity (the Coordination Center for Legal Aid Provision);

- memoranda of cooperation concluded between the Ministry of Justice of Ukraine or the Coordination Center for Legal Aid Provision and other bodies of the executive branch of power are legal acts of interdepartmental significance;

- administrative and legal regulation of provision of free legal aid is also characterized by dualism, as it is carried out in two directions, including 1) an organizational and legal one (regulatory and legal regulation to ensure the functioning of the FLA system); 2) administrative and procedural one (the provisions of the Code of Administrative Justice of Ukraine and the Code of Administrative Offenses concerning the implementation of the rules for the provision of FLA in administrative cases and cases of administrative offenses);

- the legal framework for the provision of FLA serves as a basis for defining and characterizing the content of this category as a right and guarantee for the implementation of other constitutional human and civil rights. 
In the end, we should admit that it is not possible to fully disclose the issue within the scope of one article, because the regulatory framework for the provision of FLA incorporates dozens of regulations of different legal force. Therefore, we have focused on only general issues of free legal aid in our publication. Taking our conclusions into consideration, we are of an opinion that a promising area of further research is to highlight the problems of free legal aid within the scope of its administrative and legal regulation.

\section{References:}

1. The Verkhovna Rada of Ukraine: Database "Legislation of Ukraine On free legal aid: the law of Ukraine" retrieved from : https://zakon.rada.gov.ua/laws/show/3460-17\#n246 (access date: 18.08.2019)

2. Skakun O.F. (2000). Theory of State and Law. 704 p.

3. Alekseev S.S. (1999). Law: alphabet - theory - philosophy. Experience of complex research. 712 p.

4. Sumsky D.O. (1999). Fundamentals of State and Law. 565 p.

5. Alekseev S.S. (1994). Theory of law. 220 p.

6. The Verkhovna Rada of Ukraine: The Constitution of Ukraine: Retrieved from :: https://zakon.rada.gov.ua

7. Review of the system of free legal aid in Ukraine (2017). Retrieved from : http://qala.org.ua/wpcontent/uploads/2016/04/BAR_FINAL_23_10.pdf.

8. The Verkhovna Rada of Ukraine: On international treaties of Ukraine: Retrieved from : https://zakon.rada.gov.ua/laws/show/1906-15.

9. The Verkhovna Rada of Ukraine: Convention for the Protection of Human Rights and Fundamental Freedoms: international document of 04.11 .1950 (ratified by the Law of Ukraine № 475/97-VR of 17.07.97) Retrieved from : https://zakon.rada.gov.ua/laws/show/995_004\#n42 (access date: 25/08/2019).

10. The Ministry of Justice of Ukraine: UN General Assembly Resolution 67/187 on the UN Principles and Guidelines on Access to Legal Aid in Criminal Justice Systems. Retrieved from : https://minjust.gov.ua/files/general/2013/01/09/201301090000006605.pdf (accessed 27.08.2019).

11. The Verkhovna Rada of Ukraine: Resolution on Legal Assistance and Legal Advice: International Document of the Committee of Ministers of the Council of Europe № 78 (8) of 02.03.1978. Retrieved from: https://zakon.rada.gov.ua/laws/card/994_132 (access date: 25/08/2019)

12. The Ministry of Justice of Ukraine: Bilateral international agreements in the field of international legal cooperation. Retrieved from: https://minjust.gov.ua/files/general/2013/01/09/201301090000006605.pdf.

13. Samsonov V.N. (1991). Administrative legislation: concept, content, reform. 120 p.

14. The Verkhovna Rada of Ukraine: Criminal Procedure Code of Ukraine: Law of Ukraine of 13.04.2012 № 4651-VI. Retrieved from: https://zakon.rada.gov.ua/laws/show/4651-17.

15. The Verkhovna Rada of Ukraine: Civil Procedure Code of Ukraine: Law of Ukraine of 18.03.2004 № 1618-IV. Retrieved from: https://zakon.rada.gov.ua/laws/show/4651-17.

16. The Verkhovna Rada of Ukraine: Code of Administrative Procedure of Ukraine dated 06.07.2005 № 2747-IV. Retrieved from: https://zakon.rada.gov.ua/laws/show/2747-15.

17. The Verkhovna Rada of Ukraine: Code of Ukraine on Administrative Offenses: Law of Ukraine of 07.12.1984 № 8073-X VR. Retrieved from: https://zakon.rada.gov.ua/laws/show/80731-10.

18. The Verkhovna Rada of Ukraine: On local self-government in Ukraine: the law of Ukraine of 21.05.1997 № 280/97-VR. Retrieved from: https://zakon.rada.gov.ua/laws/show/280/97-вp.

19. The Verkhovna Rada of Ukraine: On advocacy and advocacy: the law of Ukraine of 05.07.2012 № 5076-

VI. Retrieved from: https://zakon.rada.gov.ua/laws/show/5076-17 (access date: 05.09.2019)

20. The Verkhovna Rada of Ukraine: On approval of the Procedure and conditions of the competition for the selection of lawyers involved in the provision of free secondary legal aid: Resolution of the Cabinet of Ministers of Ukraine dated 28.12.2011 № 1362. Retrieved from: https://zakon.rada.gov.ua/laws/show/13622011-\%D0\%BF.

21. The Verkhovna Rada of Ukraine: On approval of the Procedure and conditions for concluding contracts with lawyers who provide free secondary legal aid on a permanent basis, and agreements with lawyers who provide free secondary legal aid on a temporary basis: Resolution of the Cabinet of Ministers of Ukraine of 11.01.2012 № 8. Retrieved from: https://zakon.rada.gov.ua/laws/show/8-2012-\%D0\%BF\#n10.

22. The Verkhovna Rada of Ukraine: On approval of the Procedure for informing the centers for free secondary legal aid about cases of detention, administrative arrest or application of a preventive measure in the form of detention: Resolution of the Cabinet of Ministers of Ukraine dated 28.12.2011 № 1363. Retrieved from: https://zakon.rada.gov.ua/laws/show/1363-2011-\%D0\%BF. 
23. The Verkhovna Rada of Ukraine: On the establishment of the Coordination Center for Legal Aid and the liquidation of the Center for Legal Reform and Draft Law under the Ministry of Justice: Resolution of the Cabinet of Ministers of Ukraine of 06.06.2012 №504. Retrieved from: https://zakon.rada.gov.ua/laws/show/504-2012-\%D0\%BF.

24. The Verkhovna Rada of Ukraine: On the Concept of formation of the system of free legal aid in Ukraine: decree of the President of Ukraine of 09.06.2006 № 509/2006. Retrieved from: https://zakon.rada.gov.ua/laws/show/509/2006.

25. The Verkhovna Rada of Ukraine: On approval of the State target program for the formation of the free legal aid system for 2013-2017: Resolution of the Cabinet of Ministers of Ukraine of 13.02.2013 № 394 . Retrieved from: https://zakon2.rada.gov.ua/laws/show/394-2013-\%D0\%BF.

26. Bandurka A.M., Gorbachev A.V. (1994). Operative-search activity: legal analysis. 160 p.

27. The Verkhovna Rada of Ukraine: On approval of quality standards for free secondary legal aid in criminal proceedings: order of the Ministry of Justice of Ukraine № 368/5 of 25.02.2014 // Database "Legislation of Ukraine". Retrieved from: https://zakon.rada.gov.ua/laws/show/z0337-14.

28. The Verkhovna Rada of Ukraine: On approval of quality standards for free secondary legal aid in criminal proceedings: order of the Ministry of Justice of Ukraine № 368/5 of 25.02.2014. Retrieved from: https://zakon.rada.gov.ua/laws/show/z0337-14.

29. The Verkhovna Rada of Ukraine: On approval of the Standard Regulations on the institution for the provision of free primary legal aid: order of the Ministry of Justice of Ukraine № 483/5 of 28.03.2012. Retrieved from: https://zakon.rada.gov.ua/laws/show/z0474-12.

30. The Verkhovna Rada of Ukraine: On approval of the Procedure for the work of the public reception center for free primary legal aid: order of the Ministry of Justice of Ukraine № 2047/5 dated 21.09.2011. Retrieved from: https://zakon.rada.gov.ua/laws/show/z1114-11.

31. The Official website of the Coordination Center for Free Legal Aid: Organizational and administrative documents. Retrieved from: https://legalaid.gov.ua/ua/zakonodavstvo/orhanizatsiino-rozporiadchidokumenty.

32. The Official website of the Coordination Center for free legal aid: On approval of Guidelines for the organization of free legal aid by local centers for free secondary legal aid: order of the Coordination Center for Legal Aid № 60 from 07/19/2019 Retrieved from: https://legalaid.gov.ua/images/docs/2019/\%D0\%9C\%D0\%B5\%D1\%82\%D0\%BE\%D0\%B4\%D0\%B0\%9C\% D0\%A0\%202019.pdf.

33. The Official website of the Coordination Center for Free Legal Aid: Memorandum of Cooperation between the National Police of Ukraine and the Ministry of Justice of Ukraine in the field of free legal aid dated 12.02.2016. Retrieved from: https://legalaid.gov.ua/images/pdfs/Memorandum_pro_spivpratsyu_btwn_police_mj.pdf. 